\title{
Protein composition in the fluid of individual bovine follicles
}

\author{
Mette M. Andersen, J. Krøll, A. G. Byskov and M. Faber \\ The Finsen Laboratory, The Finsen Institute, Strandboulevarden 49, \\ 2100 Copenhagen $\emptyset$., Denmark
}

\begin{abstract}
Summary. The proteins in follicular fluid from individual and pooled bovine follicles were studied by gel chromatography and quantitative immunoelectrophoresis. The mean protein concentration was $86.4 \%$ of serum; very large proteins were present in only low concentrations. A minimum of 40 individual proteins was distinguished in follicular fluid, and 15 of these proteins were quantitated. A correlation between molecular weight and follicular fluid:serum concentration ratio was found. Fluid from individual follicles differed only in the relative concentrations of small and large proteins. An exception to this was IgG which was occasionally, but never in healthy growing follicles, present in concentrations above $150 \%$ of serum. Healthy growing, preovulatory and atretic follicles had higher, and cystic follicles mostly lower, concentrations of small proteins than serum. The concentration of $\alpha_{2}$-macroglobulin in healthy growing follicles never exceeded $16 \%$ of serum. The concentration of large proteins in follicular fluid increased with increasing follicle size.

Attempts to detect proteins specific to follicular fluid by immunizing rabbits with pooled follicular samples and the follicular fluid proteins not bound by anti-bovine antiserum resulted in production of antibodies against fibrinogen and its split products $\mathrm{D}+\mathrm{E}$ only.
\end{abstract}

\section{Introduction}

A considerable degree of similarity exists between proteins in follicular fluid and serum (Caravaglios \& Cilotti, 1957; Matousek, 1965; Desjardins, Kirton \& Hafs, 1966; Manarang-Pangan \& Menge, 1971; Pascu, Tudorascu, Stancioiu \& Lunca, 1971; Shalgi, Kraicer, Rimon, Pinto \& Soferman, 1973), but there are differences in total protein content and in the relative concentration of the protein fractions (see Edwards, 1974, for review).

Labelled proteins have been shown to be transferred into follicular fluid after intravenous administration (von Kaulla, Aikawa \& Pettigrew, 1958; Glass, 1961; Mancini, Vilar, Heinrich, Davidson \& Alvarez, 1963; Anderson, 1972; Payer, 1975), and the follicular antrum is accessible to almost any protein present in the circulation, including ferritin (mol. wt 460,000) (Payer, 1975). It has been suggested that this accessibility might increase with the development of the follicle (Zachariae, 1958; Glass, 1961; Anderson, 1972), but there is disagreement on this point (Lipner \& Smith, 1971; Payer, 1975).

Peters, Byskov \& Faber (1973) have suggested that follicular fluid might inhibit the start of follicular growth in the immature mouse ovary, and it has been shown that bovine follicular fluid contains a component which inhibits RNA synthesis in Yoshida ascites cells in vitro (Moore et al., 1975). Since the component responsible might be a protein, we have studied the concentrations of individual proteins in follicular fluid for comparison with those of serum. Different stages of follicular development were examined for correlations with the follicular fluid proteins. Attempts were also made to produce antibodies in rabbits against proteins specific to bovine follicular fluid. 


\section{Materials and Methods}

The material for this study was obtained from 33 cows of unknown age and reproductive history at the slaughterhouse. The ovaries were removed immediately after slaughter. The size of the follicles was estimated macroscopically and fluid from the follicles was aspirated with a syringe within 2-5 min of death. The follicular fluid was (1) collected individually from 52 follicles $>5 \mathrm{~mm}$ in diameter; (2) pooled from follicles $<5 \mathrm{~mm}$ from 3 ovaries; or (3) pooled from follicles taken at random. The syringes containing the fluid were immediately placed in liquid nitrogen and thawed immediately before use.

After collection of the follicular fluid a piece of the wall was cut from 36 follicles from 21 cows. The tissue was fixed in Bouin's fluid, embedded in paraffin wax, cut into $5 \mu \mathrm{m}$ sections and stained with Heidenhain's Azan or haematoxylin and eosin. Follicles were classified as follows. (a) Healthy growing follicles were those (12) up to $15 \mathrm{~mm}$ in diameter with mitotic figures and $<2 \%$ pyknotic nuclei in the granulosa cell layer; (b) preovulatory follicles (3) were from cows judged to be within $48 \mathrm{hr}$ of oestrus and had a diameter $>20 \mathrm{~mm}$, a granulosa cell layer with $<2 \%$ pyknotic nuclei and no mitotic figures; (c) atretic follicles were those (10) of all sizes with $>2 \%$ pyknotic nuclei; (d) cystic follicles were of all sizes and were those (11) in which the granulosa cell layer consisted of a single layer of cuboidal cells.

Blood samples were taken from all the cows by cardiac puncture immediately after slaughter and serum was separated.

\section{Analysis of follicular fluid}

Total protein concentration was measured by the method described by Lowry, Rosebrough, Farr \& Randall (1951).

Follicular fluid and serum samples were subjected to gel filtration chromatography on Sephadex G-150 (type k-50, 5.0 $\times 90 \mathrm{~cm}$ : Pharmacia, Sweden) using 0.05 M-phosphate buffer, pH 7·1, at a flow rate of $30 \mathrm{ml} / \mathrm{hr}$ and recording at $280 \mathrm{~nm}$ in an LKB Uvicord. By combining the gel filtration chromatography with rocket-line immunoelectrophoresis (Krøll, 1973b), the identity of the individual proteins in the peaks was disclosed. A standard curve was drawn using the molecular weights of the corresponding human proteins as standards: albumin $(68,000)$, IgG $(160,000), \alpha_{2}$-macroglobulin $(820,000)$ and $\operatorname{IgM}(1,000,000)$ (Schultze \& Heremans, 1966). The molecular weights of the bovine proteins were estimated from this curve according to their elution pattern (Andrews, 1964).

The total number of individual serum proteins recognizable in follicular fluid was determined by line immunoelectrophoresis (Krøll, 1973a), and crossed immunoelectrophoresis (Weeke, 1973) using polyvalent anti-bovine antiserum (Dakopatts A/S, Denmark). Identification of bovine proteins was performed by absorbing the precipitates in line immunoelectrophoresis with monospecific antisera against human proteins (Krøll \& Andersen, 1975). The presence of fibrinogen and its split products $\mathrm{E}$ and $\mathrm{D}$ was investigated by absorption with monospecific antisera against these proteins. Proteins that were not identified were given numbers according to the position of the precipitin line in line immunoelectrophoresis (Andersen \& Krøll, 1975).

Rocket-line immunoelectrophoresis (Krøll, 1973b) was used to compare the proteins in follicular fluid samples and in the corresponding sera. Eleven individual proteins were quantitated. They were chosen because the staining intensity of their precipitates was strong and the day-to-day variations in position were negligible.

Rocket immunoelectrophoresis (Laurell, 1966) was used to quantitate albumin and $\operatorname{IgG}_{1}$, $\mathrm{IgG}_{2}, \mathrm{IgA}$ and IgM in follicular fluid and corresponding sera. These proteins were too weak or broad in the rocket-line precipitin pattern for accurate measurements. The albumin measurements served as a control.

\section{Immunization experiments}

Three types of experiments were carried out. (1) Three rabbits were immunized with pooled random follicular fluid (for protocol, see Harboe \& Ingild, 1973). (2) Two rabbits were immunized with 
antigens contained in agarose gel prepared by line immunoelectrophoresis with polyvalent antibovine antiserum in the antibody gel and pooled random follicular fluid as antigen in the trough. The anodic part of the gel was covered by a cellulose bag to catch those proteins which were not precipitated by the antiserum. After electrophoresis the content of the cellulose bag was carefully removed and homogenized in a Potter-Elvehjem tissue grinder and used as immunogen. (3) Two rabbits were immunized with the eluate from an affinity chromatography column prepared as follows: polyvalent anti-bovine antiserum $(2 \mathrm{ml})$ was coupled to $\mathrm{CNBr}$-Sepharose $4 \mathrm{~B}$ (Pharmacia, Sweden) as prescribed by the supplier, $30 \mu$ pooled random follicular fluid were applied and the effluent recorded at $280 \mathrm{~nm}$ in an LKB Uvicord. The protein content in the eluate was below detection, demonstrating that more than $99 \%$ of total follicular fluid proteins were bound to the column. Elution was terminated at $200 \mathrm{ml}$ and the eluate concentrated to $10 \mathrm{ml}$ in a dialysis bag. The concentrate was used for immunization.

Immunization was continued for more than 18 months in all rabbits and blood taken every 2nd month. All the resulting antisera were tested in line immunoelectrophoresis, using pooled random follicular fluid as antigen. Polyvalent anti-bovine antiserum was applied on each plate for comparison (Krøll, 1973a).

\section{Results}

\section{Total protein concentration}

As shown in Table 1 this was fairly constant regardless of the size of the follicle.

Table 1. Total protein concentration in individual bovine follicles

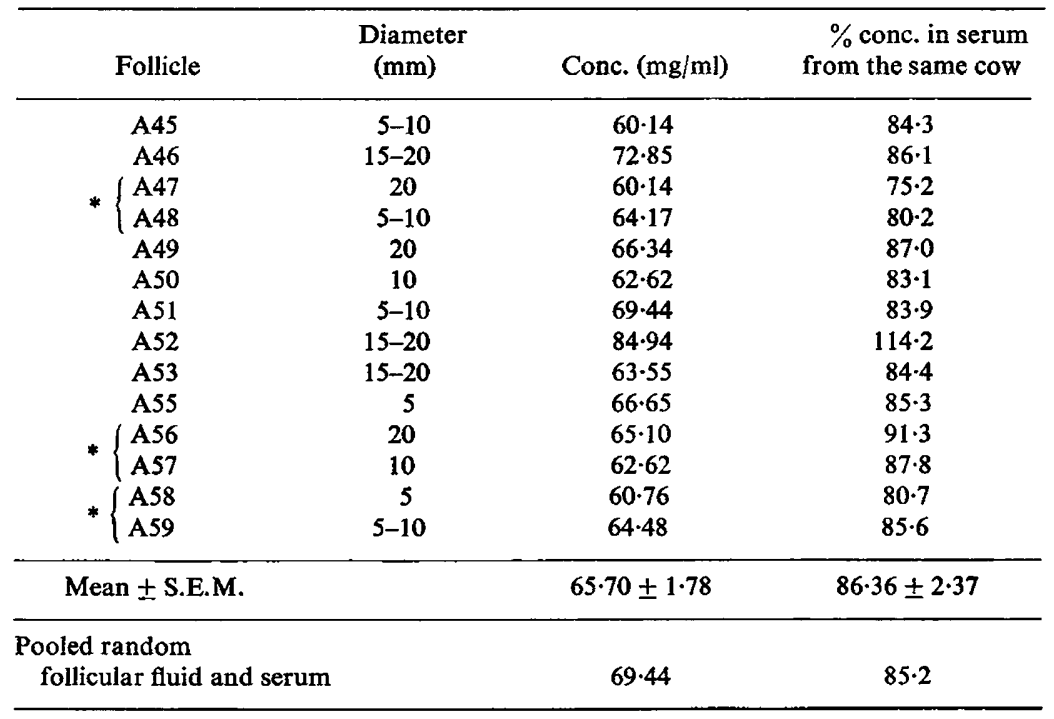

*Follicles from the same ovary.

\section{Gel filtration chromatography and molecular weight}

Three major protein peaks were distinguished in pooled random follicular fluid and in standard serum (Flow Laboratories, Scotland). Rocket-line immunoelectrophoresis revealed that Peak A contained proteins with molecular weights above 250,000 , Peak B proteins had molecular weights between 110,000 and 250,000 , and Peak $C$ proteins were smaller than 110,000 . Weighing of the areas under the peaks revealed that Peak A (Fractions 16-46) constituted $21.5 \%$ of the total area in serum 
and $11.2 \%$ of the total area in follicular fluid, Peak B (Fractions $47-90$ ) $33 \cdot 7 \%$ and $39 \cdot 3 \%$ of the respective areas, and Peak C (Fractions $91-165$ ) constituted $44.8 \%$ and $49.5 \%$ of the areas. The absolute sizes of Peaks B and C were almost identical in the follicular fluid and serum, whilst Peak A in follicular fluid was only $44.9 \%$ of Peak $A$ in serum. The lower protein concentration in follicular fluid seems to be due to a lower concentration of the very large proteins only. The molecular weights of the individual proteins found are listed in Table 2.

Table 2. Molecular weights of proteins found in bovine follicular fluid by rocket-line immunoelectrophoresis

\begin{tabular}{rlr}
\hline Line no. & \multicolumn{1}{c}{ Protein } & Mol. wt \\
\hline 3 & Prealbumin & 55,000 \\
1 & Albumin & $68,000^{*}$ \\
10 & Gc-globulin & 68,000 \\
7 & $-\dagger$ & 79,000 \\
5 & $-\dagger$ & 80,000 \\
4 & $-\dagger$ & 82,000 \\
11 & $-\dagger$ & 100,000 \\
24 & $\beta_{2}$-glycoprotein III & 145,000 \\
18 & IgG & $160,000^{*}$ \\
17 & $-\dagger$ & 170,000 \\
12 & $\alpha_{1}-$ lipoprotein & 260,000 \\
27 & $\alpha_{2}$-macroglobulin & $820,000^{*}$ \\
32 & IgM & $1,000,000^{*}$ \\
\hline
\end{tabular}

*Standards taken from weights of corresponding human proteins (Schultze \& Heremans, 1966).

†Protein not identified.

\section{Total number of proteins}

In pooled random follicular fluid samples, a minimum of 37 individual precipitates was distinguished by line immunoelectrophoresis and 40 by crossed immunoelectrophoresis, including fibrinogen and its split products $\mathbf{E}$ and $\mathrm{D}$. Identical numbers have been distinguished in bovine serum (Andersen \& Krøll, 1975).

\section{Individual follicular fluid and serum proteins in the same animal}

A close similarity in protein composition was seen between follicular fluids and sera, and individual differences in sera were reflected in follicular fluid samples (Pl. 1, Fig. 1).

Analysis of the protein composition of fluid from single follicles (Table 3 ) revealed that the ratios of the small molecular weight proteins (Nos 10, 7, 5 and 4) were similar in all follicles. With increasing molecular weight, however, the protein ratios differed. The greatest variation was in $\alpha_{2}$-macroglobulin and 5 follicles with a high $\alpha_{2}$-macroglobulin ratio (A44, A46, A52, A57 and A58) also had high $\alpha_{1^{-}}$ lipoprotein ratios.

\section{EXPLANATION OF PLATE 1}

Fig. 1. Rocket-line immunoelectrophoresis of bovine follicular fluid samples and sera. The antibody gel was cast in three sections containing $1.5 \mu \mathrm{l} / \mathrm{cm}^{2}, 5 \mu \mathrm{l} / \mathrm{cm}^{2}$ and $10 \mu l$ antiserum $/ \mathrm{cm}^{2}$ towards the anode (top). The trough contained $20 \mu l$ standard bovine serum. Wells A and B (standards) contained $3 \mu l(1+40)$ and $3 \mu \mathrm{l}(1+10)$ pooled bovine serum. The other wells contained $3 \mu l(1+20)$ follicular fluid or serum (S). Follicle 52 was taken from the same cow as serum sample 9: note that the relatively high concentration of line No. 7 in $S_{9}$ is reflected in the corresponding follicular fluid sample. Follicles 53 and 54 were taken from the same cow as serum sample 10: note the similar appearance of line No. 10 in these samples. Albumin concentrations (line No. 1) are higher in follicular fluids than in their respective sera, and $\alpha_{2}$-macroglobulin concentrations (line No. 27) are much lower. 
PLATE 1

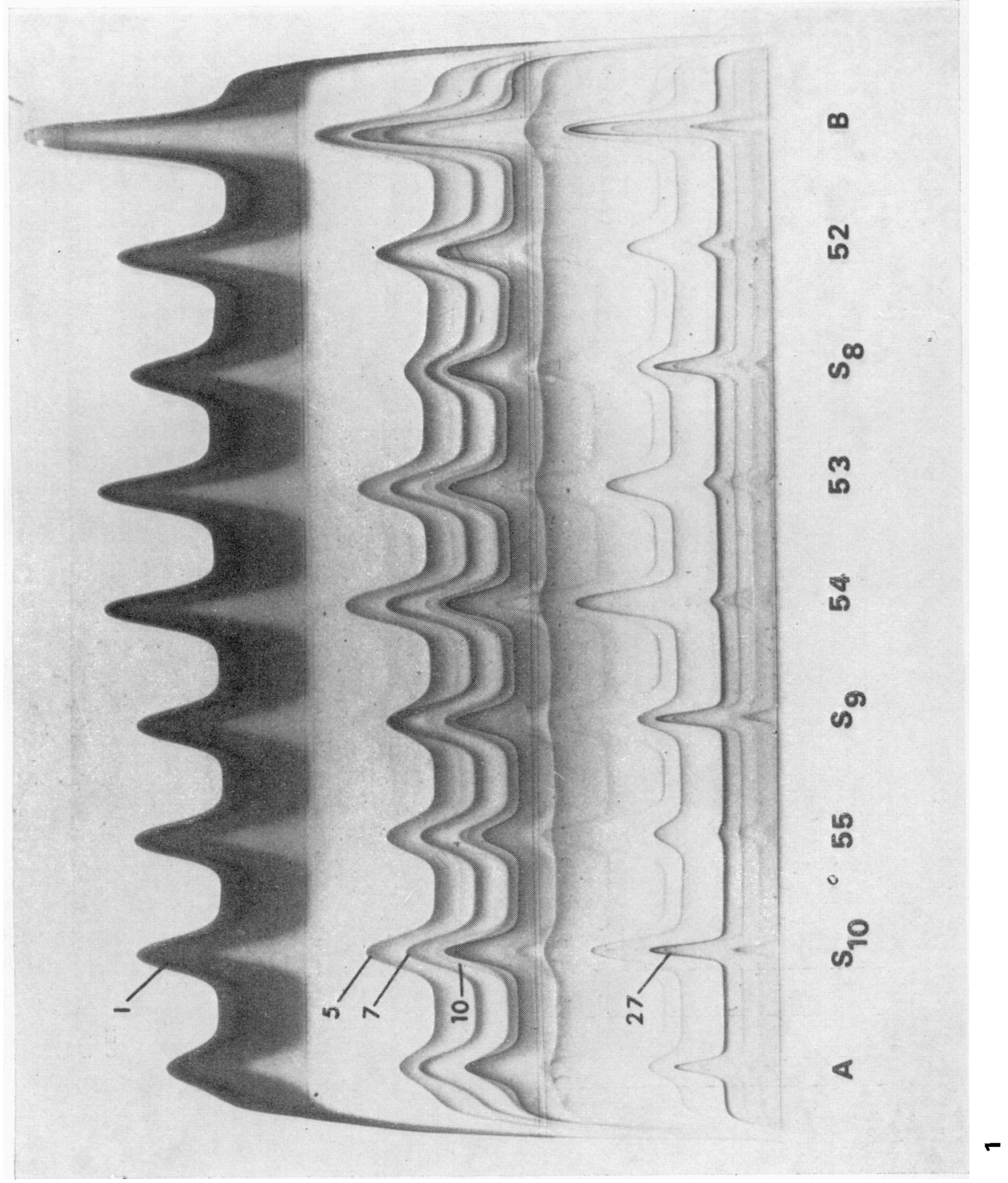


PLATE 2

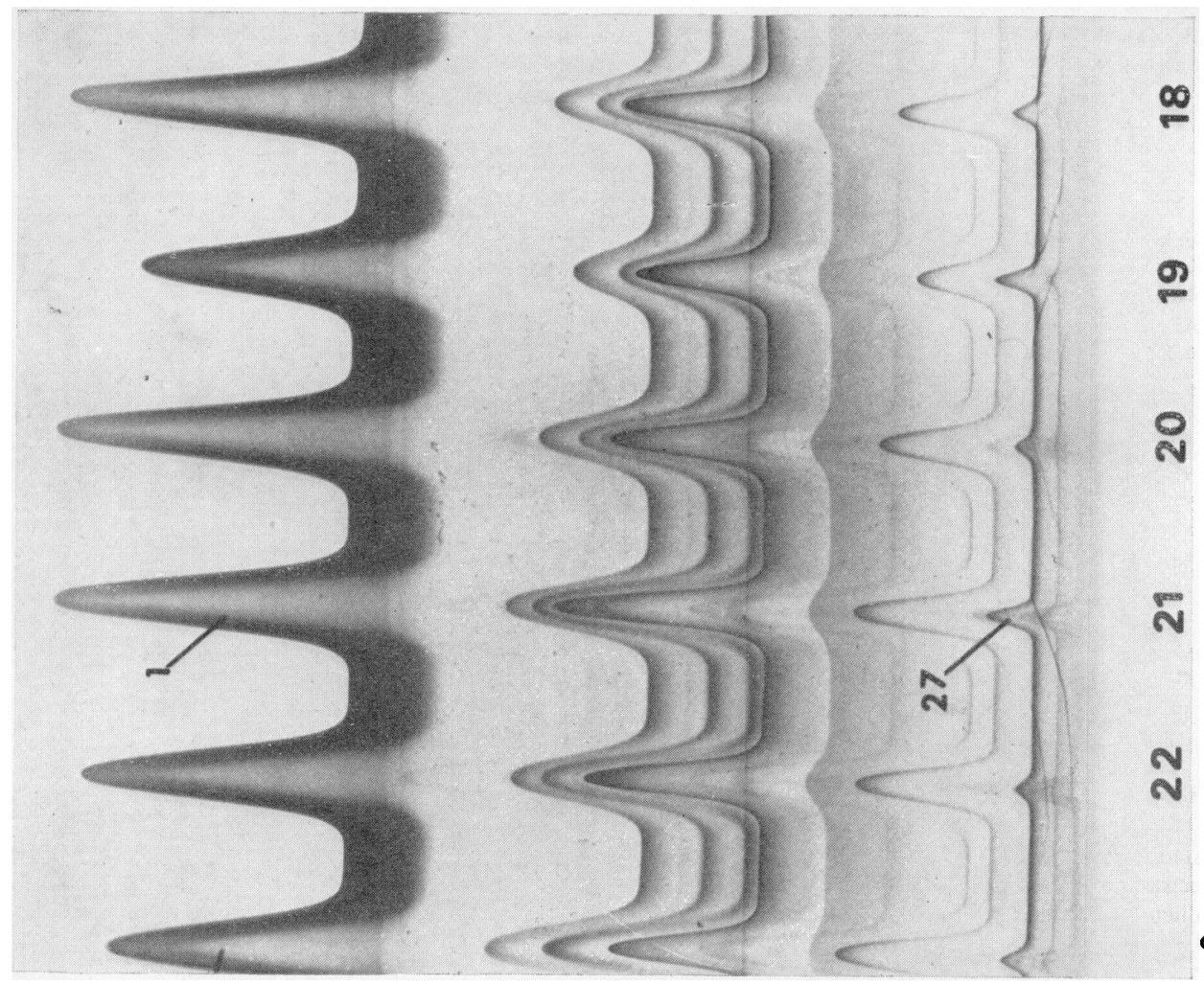

$m$

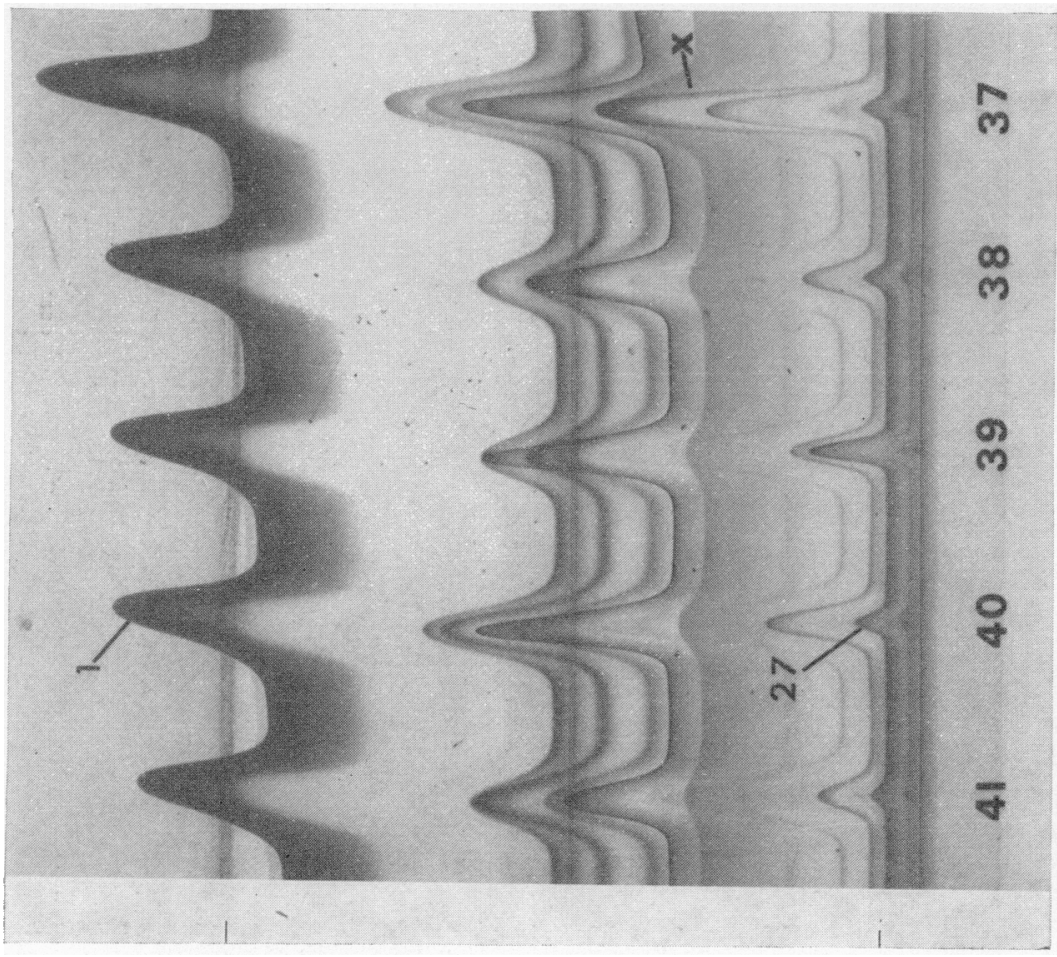


Table 3. The follicular fluid:serum concentration ratio (expressed as conc. in follicular fluid/conc. in serum:conc. of albumin in follicular fluid/conc. of albumin in serum $\times 100$ ) of 10 proteins in individual bovine follicles

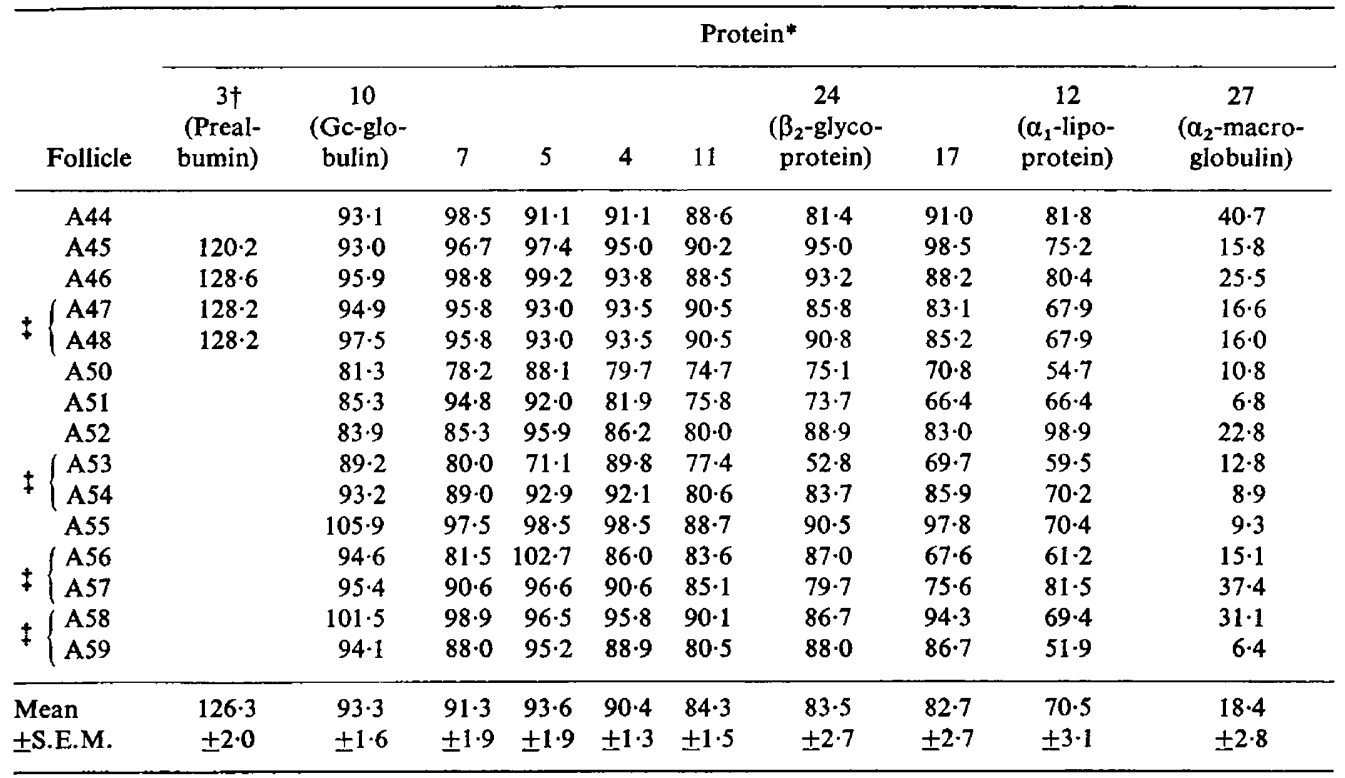

* Listed in order of molecular weight (see Table 2).

†Precise quantitation was only possible for 4 follicles, values for other follicles were of the same magnitude.

¥Follicles from the same ovary.

The mean albumin concentrations in follicular fluid samples varied between $97 \%$ and $141 \%$ of serum albumin (Table 4). Since the behaviour of small proteins (mol. wt 68,000-82,000) was similar in all the follicles, these differences in albumin concentration express variations in concentration of all the small proteins. When pairs of follicles from the same ovaries were studied, similar albumin concentrations were found in A47 and A48, and A53 and A54, but there was a difference of $10 \%$ for A56 and A57 and $15 \%$ for A58 and A59.

The $\mathrm{IgG}_{1}$ and $\mathrm{IgG}_{2}$ concentrations were very similar in all follicles, suggesting that the ovarian follicle does not distinguish between these two immunoglobulins, although the concentrations varied markedly between individual follicles, even those (A47 and A48) from the same ovary.

Some modification of follicular IgA might have occurred since the precipitate in the immunoelectrophoresis was less distinct than that from serum.

\section{EXPLANATION OF PLATE 2}

Fig. 2. Rocket-line immunoelectrophoresis of fluids from 1 preovulatory follicle (37), 3 individual cysts from another cow $(38,39,40)$, and 1 healthy growing follicle from a third cow (41). Applications were as described in P1. 1, Fig. 1. The $\alpha_{2}$-macroglobulin concentration (line No. 27) was low in the healthy growing follicles, and the cysts differed in concentration of this protein. Cyst 39 was very large ( $50 \mathrm{~mm}$ in diameter) and contained more than twice as much $\alpha_{2}$-macroglobulin as any of the other samples, despite having a similar albumin concentration (line No. 1). The preovulatory follicle contained an unidentified protein (X) not seen in any other fluid samples.

Fig. 3. Rocket-line immunoelectrophoresis of fluid from 1 preovulatory (18) and 1 cystic follicle (19), and pooled follicles $<5 \mathrm{~mm}$ in diameter (20) from one cow and of fluid from 1 preovulatory follicle (21) and pooled follicles $<5 \mathrm{~mm}$ in diameter (22) from another cow. Applications were as described in Pl. 1 , Fig. 1. Follicle 18 had a similar protein composition to that in the pooled small follicles (20), but there was a low albumin concentration (line No. 1) and high $\alpha_{2}$-macroglobulin (line No. 27) concentration in the cystic follicle (19). Follicle 21 had a slightly higher albumin concentration and much higher $\alpha_{2}$-macroglobulin concentration than the pooled small follicles from the same cow. 
Table 4. Concentration of albumin and immunoglobulins in individual follicles (expressed as a $\%$ of that in serum from the same cows)

\begin{tabular}{|c|c|c|c|c|c|}
\hline Follicle & Albumin & $\operatorname{IgG}_{1}$ & $\mathrm{IgG}_{2}$ & IgA & $\mathrm{IgM}$ \\
\hline A44 & $110 \cdot 0$ & $67 \cdot 5$ & $83 \cdot 0$ & $27 \cdot 6$ & $7 \cdot 5$ \\
\hline A45 & 110.6 & 116.6 & 113.8 & $37 \cdot 5$ & $2 \cdot 3$ \\
\hline A46 & $97 \cdot 3$ & $97 \cdot 5$ & $84 \cdot 8$ & $33 \cdot 5$ & $7 \cdot 8$ \\
\hline * A47 & 123.6 & $197 \cdot 5$ & $165 \cdot 1$ & 21.9 & $3 \cdot 5$ \\
\hline * $\{$ A48 & $124 \cdot 6$ & $120 \cdot 1$ & $117 \cdot 6$ & $43 \cdot 0$ & $3 \cdot 4$ \\
\hline A49 & $105 \cdot 5$ & $87 \cdot 7$ & 87.9 & $31 \cdot 3$ & $2 \cdot 8$ \\
\hline A50 & $122 \cdot 3$ & 78.9 & 68.9 & $25 \cdot 7$ & $0 \cdot 3$ \\
\hline A51 & $141 \cdot 0$ & $137 \cdot 0$ & $128 \cdot 8$ & $41 \cdot 4$ & 1.0 \\
\hline A52 & $99 \cdot 3$ & $74 \cdot 2$ & $71 \cdot 5$ & 39.8 & $7 \cdot 7$ \\
\hline * $\int \mathrm{A} 53$ & 121.0 & $86 \cdot 9$ & $88 \cdot 2$ & 32.8 & $1 \cdot 8$ \\
\hline A54 & 118.0 & $72 \cdot 3$ & - & 16.9 & - \\
\hline A55 & 97.6 & $104 \cdot 5$ & $104 \cdot 5$ & $29 \cdot 7$ & 0.7 \\
\hline f A56 & $111 \cdot 3$ & $84 \cdot 3$ & $84 \cdot 2$ & $13 \cdot 6$ & $2 \cdot 0$ \\
\hline$*\{$ A57 & $123 \cdot 3$ & $112 \cdot 5$ & $135 \cdot 1$ & $34 \cdot 1$ & $11 \cdot 9$ \\
\hline - A58 & 98.0 & 76.0 & 91.9 & $17 \cdot 1$ & $5 \cdot 3$ \\
\hline * $\{$ A59 & $113 \cdot 3$ & 84.0 & $96 \cdot 4$ & $29 \cdot 4$ & 1.4 \\
\hline Mean \pm S.E.M. & $113 \cdot 5 \pm 3 \cdot 1$ & $99 \cdot 8 \pm 8 \cdot 2$ & $101 \cdot 4 \pm 6.8$ & $29.7 \pm 2 \cdot 2$ & $4.0 \pm 0.87$ \\
\hline
\end{tabular}

*Follicles from the same ovary.

The 5 follicles which had an increase in $\alpha_{2}$-macroglobulin and $\alpha_{1}$-lipoprotein all exhibited increased IgM concentrations. When a rise in concentration of high molecular weight proteins in individual follicles occurs, therefore, all such proteins are affected and the concentration of $\alpha_{2}$-macroglobulin in follicular fluid can be used as an indicator for this.

There is a significant correlation $(r=0.96 ; P<0.001)$ between the size of the protein and its follicular fluid: serum concentration ratio (Text-fig. 1).

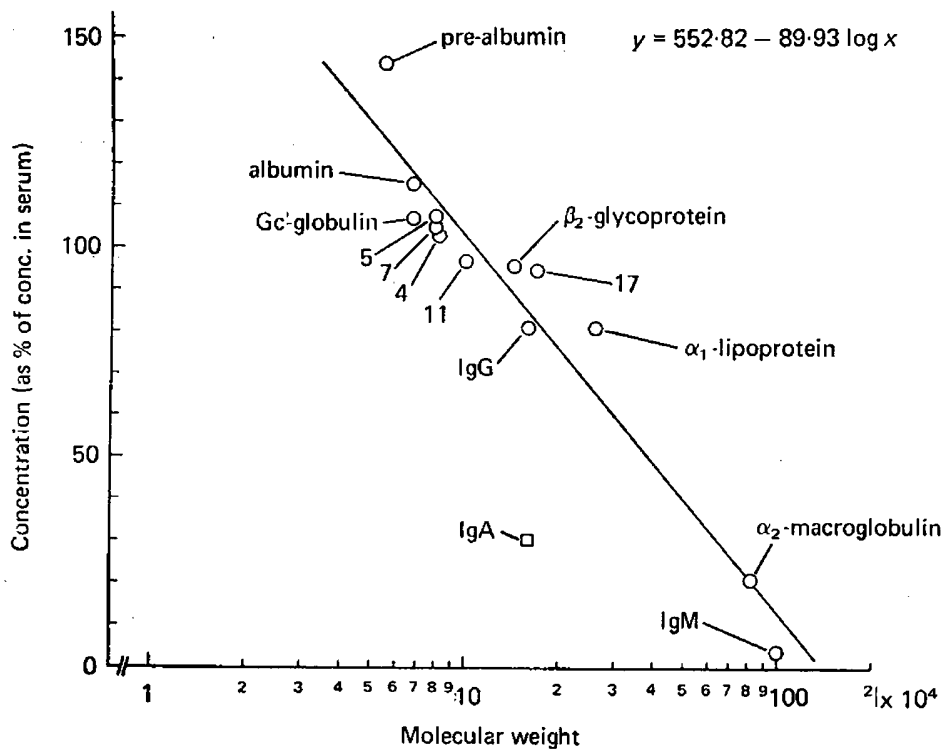

Text-fig. 1. The relationship between the mean follicular fluid:serum concentration ratio and molecular weight of 15 individual proteins from cow follicles. Values taken from Table 3 were multiplied by 113.5 (the follicular fluid:serum albumin ratio). The values for IgA were not included in the equation since it is not known whether this protein is present in its monomeric or polymeric configuration. $\operatorname{IgG}_{1}$ and $\mathrm{IgG}_{2}$ were treated identically and a concentration of $81 \cdot 2 \%$ was used for IgG. 


\section{Follicular morphology}

In follicles diagnosed as healthy and growing, variations in protein composition were minimal, and if present affected all proteins. The concentrations of large proteins were very low, e.g. $\alpha_{2^{-}}$ macroglobulin concentration never exceeded $16 \%$ of that in pooled serum. In the 3 preovulatory follicles the concentration of small proteins was at the upper limit for healthy growing follicles and the concentration of large proteins exceeded that found in healthy growing follicles. The concentration of IgG was comparable to that of other large proteins in two of the follicles, but in the third the IgG concentration was $150 \%$ of that in pooled serum. This follicle contained an unidentified protein not seen in any other sample (PI. 2, Fig. 2).

In atretic follicles the composition of smaller proteins did not differ from that of healthy growing or preovulatory follicles. The concentrations of large proteins, however, varied considerably, and were generally higher than those in healthy growing follicles from the same ovary. An IgG concentration above pooled serum values was found in one atretic follicle only.

In cystic follicles the protein pattern was more variable. In two cystic follicles the IgG concentration was more than $150 \%$ of pooled serum and in one of these the concentration of $\alpha_{2}$-macroglobulin and IgM was also higher than in serum. This cyst contained a second unidentified protein not seen in other fluid samples.

In fluid pooled from small follicles the protein patterns were similar to those in large follicles in the same ovaries (PI. 2, Fig. 3).

The mean $\alpha_{2}$-macroglobulin concentration of all the samples was $19 \cdot 2 \%$ of serum; that in healthy growing follicles was lowest $(10.2 \%)$ and that in atretic, preovulatory and cystic follicles was higher $\left(18 \cdot 6,23 \cdot 3\right.$ and $29 \cdot 7 \%$, respectively). Irrespective of morphology, the $\alpha_{2}$-macroglobulin concentration increased with increasing follicle size: follicles having a diameter of 5-10 mm had $11 \cdot 8 \%$, follicles of $10-15 \mathrm{~mm}$ had $19.0 \%$, follicles of $15-20 \mathrm{~mm}$ had $25.9 \%$, and those $>20 \mathrm{~mm}$ had $29.2 \%$ of pooled serum. Nineteen follicular fluid samples had an $\alpha_{2}$-macroglobulin concentration above $16.0 \%$ of pooled serum; 6 came from atretic follicles, 10 from cystic and 3 from the preovulatory follicles. None was healthy and growing. An $\alpha_{2}$-macroglobulin concentration above $16 \%$ of pooled serum can therefore be used as a criterion to exclude healthy growing follicles, but the concentrations below $16 \%$ do not signify normality, since one cyst and 4 atretic follicles were missed by this criterion.

\section{Evaluation of experimental antisera}

Each of the three rabbits which were immunized with pooled follicular fluid had their antisera tested separately. The number and strength of precipitates given by the antisera against follicular fluid varied between rabbits and between bleedings, but no precipitate was found with any of the antisera which was not also present with anti-bovine antiserum.

The antisera from rabbits immunized with antigens embedded in agarose gel gave only 2-3 precipitates against follicular fluid. By line-absorption they were shown to be fibrinogen and its split products.

Immunizations with antigens not bound by affinity chromatography had to be continued for 6 months before any precipitates could be produced and these were due to fibrinogen and its split products. Thus neither of our immunizations produced precipitating antibodies against proteins specific to follicular fluid.

\section{Discussion}

The results from the present study demonstrate that a minimum of 40 serum proteins, as well as fibrinogen and its split products, is present in bovine follicular fluid. IgM is always present, although 
in low concentrations, indicating that the bovine follicle is accessible to proteins of molecular weight $1,000,000$. The mean follicular fluid:serum concentration ratio of 15 proteins was inversely correlated to the molecular size, except for minor differences which might be due to individual molecular characteristics or the experimental errors inherent in gel chromatography causing retention of glycoproteins (Andrews, 1964). Thus our results strongly support the hypothesis that follicular fluid proteins are derived from serum by filtration. One possible exception was that of IgG which was occasionally (but never in healthy growing follicles) present in concentrations above $150 \%$ of serum, although these high concentrations might be related to leucocytes and plasma cells which are known to invade preovulatory and atretic follicles of the cow (Marion, Gier \& Choudary, 1968; Priedkalns, Weber \& Zemjanis, 1968).

Several studies have demonstrated that a continuous protein equilibrium exists between plasma and follicular fluid, and that the total protein concentration is similar in small and large follicles (Caravaglios \& Cilotti, 1957; Yatvin \& Leathem, 1964; Desjardins et al., 1966; Pascu et al., 1971; McGaughey, 1975) and our results confirm this since the follicular fluid:serum total protein concentration was similar irrespective of follicle size. Moreover the protein composition of fluid pooled from follicles $<5 \mathrm{~mm}$ in diameter was indistinguishable from that of large single follicles. Therefore, claims of a separate existence of primary and secondary follicular fluid (see Edwards, 1974) are not supported by these findings.

The protein composition in healthy growing follicles differed from that of atretic and cystic follicles only in the relative concentrations of small and large proteins and suggests that if granulosa cells do play a role in follicular fluid accumulation it is not a direct one. Increasing follicle size was found to be associated with a higher concentration of large proteins in the follicular fluid. Since preovulatory swelling is dependent on increasing capillary clearance (Lipner \& Smith, 1971; Bjersing \& Cajander, 1974), a relatively higher concentration of large proteins in preovulatory follicles could be due to the 'stretched pore phenomenon' (for reviews see Giese, 1973; Parving, 1975). Bovine follicles expand rapidly with the onset of atresia (Gier \& Marion, 1967) and the high concentration of large proteins in atretic and cystic follicles might also be due to this phenomenon, although degenerative changes are probably involved.

Follicles are drained by the local lymph and venous systems (Burr \&Davies, 1951; Gilloux, 1957; Czeizel \& Palkovich, 1962). Our findings that the smaller proteins are found in higher concentration in follicular fluid than in serum are in agreement with previous findings for albumin (Shalgi et al., 1973; McGaughey, 1975) and that the protein composition of follicular fluid is relatively constant compared to the cyclic changes in lymph (Morris \& Sass, 1966) suggest that proteins can not escape freely from the follicle. By this retention of proteins follicular fluid can probably maintain a colloid osmotic pressure equal to serum since the smaller proteins compensate for the absence of large proteins. However, simultaneous measurements of follicular fluid and capillary colloid osmotic pressure have not yet been carried out.

The failure to detect follicle-specific proteins with the immunization experiments is in agreement with previous negative results (Manarang-Pangan \& Menge, 1971; Beck \& Sheldon, 1972). The only proteins found which were absent from serum were fibrinogen and its split products $D$ and $E$. One preovulatory and one cystic follicle were seen which contained unidentified proteins not present in any other samples. The fact that these proteins were found during immunoelectrophoresis against anti-bovine antiserum suggests that they were serum proteins. Our findings do not support the hypothesis that specific proteins in follicular fluid may influence ovarian development (Peters et al., 1973; Moore et al., 1975), although the presence of proteins in follicular fluid unable to elicit precipitating antibodies, or in concentrations below detection by the present methods, cannot be ruled out.

We thank Dr P. Nansen, The Royal Veterinary and Agricultural University, Copenhagen, for pooled bovine serum; Dr K. B. Pedersen, The State Veterinary Serum Laboratory, Copenhagen, for monospecific anti-IgG ${ }_{1}$ and anti-IgA; Dr V. Kruse, National Institute of Animal Science, Copenhagen, for monospecific anti-IgG ${ }_{2}$; Dr J. E. Butler, Department of Microbiology, University of Iowa for monospecific anti-IgM; and Mrs L. Ahrenst, Mr Jens Konnerup Madsen and Mrs B. Larsen for technnịcal assistance. 


\section{References}

ANDERSEN, M.M. \& KRøLL, J. (1975) Identification of bovine serum proteins by quantitative immunoelectrophoretic methods. Scand. J. Immunol. 4, Suppl. 2, 163-171.

ANDERSon, W.A. (1972) Permeability of ovarian blood vessels and follicles of juvenile rats. Microvasc. Res. 4, 348-373.

ANDREws, P. (1964) Estimation of the molecular weights of proteins by sephadex gel-filtration. Biochem. J. 91, 222-233.

BECK, L.R. \& SHELDEN, R.M. (1972) Antigenicity of rat follicular fluid. Fert. Steril. 23, 910-914.

BJersing, L. \& CAJANDER, S. (1974) Ovulation and the mechanism of follicle rupture. VI. Ultrastructure of theca interna and the inner vascular network surrounding rabbit Graafian follicles prior to induced ovulation. Cell Tiss. Res. 153, 31-44.

BURR, J.H. \& DAviEs, J.I. (1951) The vascular system of the rabbit ovary and its relationship to ovulation. Anat. Rec. 111, 273-292.

Caravaglios, R. \& Cilotti, R. (1957) A study of the proteins in the follicular fluid of the cow. J. Endocr. 15, 273-278.

Czeizel, E. \& Palkovich, I. (1962) Die Rolle der Lymphzirkulation bei der Entstehung der Follikularzystem des Eierstockes. Zentbl. Gynäk. 11, 418-426.

Desjardins, C., Kirton, K.T. \& Hafs, H.D. (1966) Some chemical, immunochemical and electrophoretic properties of bovine follicular fluid. J. Reprod. Fert. 11, 237-244.

Edwards, R.G. (1974) Follicular fluid. J. Reprod. Fert. 37, 189-219.

Gier, H.T. \& Marion, G.B. (1967) Size changes in bovine atretic graafian follicles.J. Dairy Sci. 50, 1001 .

GIESE, J. (1973) Renin, angiotensin and hypertensive vascular damage: a review. Am. J. Med. 55, 315-332.

Gilloux, A. (1967) Recherches expérimentales sur la pathogénie des troubles trophiques de l'ovaire. Gynéc. Obstét. 66, 455-464.

GLASS, L.E. (1961) Localization of autologous and heterologous serum antigens in the mouse ovary. Devl Biol. 3, 787-804.

HARBoE, N. \& INGILD, A. (1973) Immunization, isolation of immunoglobulins, estimation of antibody titre. In $A$ Manual of Quantitative Immunoelectrophoresis: Methods and Applications, pp. 161-164. Eds N. H. Axelsen, J. Krøll \& B. Weeke. Universitetsforlaget, Oslo.

KRøLL, J. (1973a) Line immunoelectrophoresis. In A Manual of Quantitative Immunoelectrophoresis; Methods and Applications, pp. 61-67. Eds N. H. Axelsen, J. Krøll \& B. Weeke. Universitetsforlaget, Oslo.

KRøLL, J. (1973b) Rocket-line immunoelectrophoresis (76). In A Manual of Quantitative Immunoelectrophoresis; Methods and Applications, pp. 83-87. Eds N. H. Axelsen, J. Krøll \& B. Weeke. Universitetsforlaget, Oslo.

KrøLl, J. \& ANDERSEN, M.M. (1975) Identification of immunoprecipitates in line immunoelectrophoresis. J. Immunol. Meth. 9, 141-146.
LAURELL, C.-B. (1966) Quantitative estimation of proteins by electrophoresis in agarose gel containing antibodies. Analyt. Biochem. 15, 45-52.

LIPNER,H. \& SMITH, M.S. (1971) A method for determining the distribution and source of protein in preovulatory rat ovaries. $J$. Endocr. 50, 187-200.

Lowry, O. H., Rosebrough, N.J., FARr, A.L. \& RANDALL, R.H. (1951) Protein measurement with the folin phenol reagent. J. biol. Chem. 193, 265-275.

Manarang-Pangan, S. \& Menge, A.C. (1971) Immunologic studies on human follicular fluid. Fert. Steril. 22, 367-372.

Mancini, R.E., Vilar, O., Heinrich, J.J., Davidson, O.W. \& Alvarez, B. (1963) Transference of circulating labeled serum proteins to the follicle of the rat ovary. J. Histochem. Cytochem. 11, 80-88.

MARION, G.B., Gier, H.T. \& ChOUdARY, J.B. (1968) Micromorphology of the bovine ovarian follicular system. J. Anim. Sci. 27, 451-477.

MATOUSEK, J. (1965) Antigenicity and polymorphism of the ovarian follicle fluids in cows. In Blood Groups of Animals. Proc. 9th Eur. Blood Gp. Conf., Prague p. 359.

MCGaugheY, R.W. (1975) A comparison of the fluids from small and large ovarian follicles of the pig. Biol. Reprod. 13, 147-153.

Moore, G.P.M., Lintern-Moore, S., Peters, H., Byskov, A.G., ANDersen, M. \& Faber, M. (1975) The inhibition of DNA-dependent RNA synthesis in Yoshida ascites cells by bovine follicular fluid. J. Cell. Physiol. 86, 31-36.

Morris, B. \& SAss, M.B. (1966) The formation of lymph in the ovary. Proc. $R$. Soc. $B$ 164, 577-591.

PARVING, H.-H. (1975) Microvascular permeability to plasma proteins in hypertension and diabetes mellitus in man-on the pathogenesis of hypertensive and diabetic microangiopathy. Thesis, The University of Copenhagen.

Pascu, T., Tudorascu, R., Stanciolu, N. \& Lunca, H. (1971) Concentration des protéines totales et des fractions protéiniques dans le liquide folliculaire normal, pendant les différentes phases du cycle oestral, et dans le liquide des cystes folliculaires ovariens, ainse que dans le sang des mêmes vaches. Recl Méd. vét. Éc. Alfort 147, 979-991.

PAYer, A.F. (1975) Permeability of ovarian follicles and capillaries in mice. Am. J. Anat. 142, 295-318.

Peters, H., Byskov, A.G. \& Faber, M. (1973) Intraovarian regulation of follicle growth in the immature mouse. In The Development and Maturation of the Ovary and its Functions, pp. 20-23. Ed. H. Peters. International Congress Series No. 267. Excerpta Medica, Amsterdam.

Priedkalns, J., Weber, A.F. \& Zemjanis, R. (1968) Qualitative and quantitative morphological studies of the cells of the membrana granulosa, theca interna and corpus luteum of the bovine ovary. Z. Zellforsch. mikrosk. Anat. 85, 501-520.

Schultze, H.E. \& Heremans, J.F. (1966) Molecular Biology of Human Proteins with Special Reference to Plasma Proteins. Elsevier Publishing Company, Amsterdam. 
Shalgi, R., Kraicer, P., Rimon, A., Pinto, M. \& Soferman, N. (1973) Proteins of human follicular fluid: the blood-follicle barrier. Fert. Steril. 24, 429434.

von Kaulla, K.N., Aikawa, J. K. \& Pettigrew, J.D. (1958) Concentration in the human ovarian follicular fluid of radioactive tracers and drugs circulating in the blood. Nature, Lond. 182, 1238-1239.

WeEKE, B. (1973) Crossed immunoelectrophoresis. In
A Manual of Quantitative Immunoelectrophoresis; Methods and Applications, pp. 47-56. Eds N. H. Axelsen, J. Krøll \& B. Weeke. Universitetsforlaget, Oslo.

YATVIN, M.B. \& LeATHEM, J.H. (1964) Origin of ovarian cyst fluid: studies on experimentally induced cysts in the rat. Endocrinology 75, 733-740.

ZACHARIAE, F. (1958) Studies on the mechanism of ovulation. Acta endocr., Copenh. 27, 339-342.

Received 5 February 1976 